\title{
ER, PR, M1B1 index and HER2/NEU status in 100 cases of Breast Carcinoma
}

\author{
Trivedi P.P., Goel D. K. ${ }^{2}$, Patel S. ${ }^{3}$, Jetly D.H. ${ }^{4}$ \\ ${ }^{1}$ Dr. Priti P. Trivedi, Associate Professor, ${ }^{2}$ Dr. Deepak K. Goel, Resident Doctor, ${ }^{3}$ Dr. Silky Patel, Consultant Pathologist, \\ ${ }^{4}$ Dr. Dhaval H. Jetly, Associate Professor and Head of the Department; all authors are affiliated with Department of \\ Pathology, Gujarat Cancer Research Institute, Ahmedabad, Gujrat, India.
}

Corresponding Author: Dr. Deepak K. Goel, Resident Doctor, Department of Pathology, Gujarat Cancer Research Institute, Ahmedabad, India. E-mail: drdpkgoel@gmail.com

\begin{abstract}
Background: Breast carcinomas are the most common cancers in women in our country. There have been various studies about the markers like ER/PR, HER2/NEU, HRAS, p53, Ki67 predicting response along with morphology and mitotic count. Aim: To find out the prevalence of various molecular subtypes of breast cancers and correlate molecular subtypes and M1B1 index with histological features, clinical stage and other prognostic factors. Materials and Methods: It is a prospective study of 100 cases of breast cancer operated in our hospital. All specimens were grossed and then stained using hematoxylin and eosin staining. They were staged according to TNM classification and further processed for immunostaining (ER, PR, Her2/neu and M1B1). Results: Luminal A is the most common subtype and is associated with lower clinical stage. Higher M1B1 index is associated with higher aggressiveness.
\end{abstract}

Keywords: Breast carcinoma, ER/PR, Her2/neu, M1B1 index, Histological grade.

\section{Introduction}

Carcinoma of breast has been rising steadily and has become the most common cancer in women in India $[1,2]$ To detect it at early stage awareness must be created about its risk factors and regular screening must be carried out through breast self-examination and mammography [3].

Till now, morphology has been the cornerstone for the characterization of breast cancer prognosis. There are ancillary markers also to predict response to treatment and prognosis like ER/PR, HER2/NEU, HRAS, p53 etc. As tumours with high mitotic count tend to be more aggressive, in recent years immunohistochemistry for Ki-67 has also been used to determine tumour proliferation [4].

Breast carcinoma has been sub classified into four subtypes based on gene expression profiling using DNA microarray which is a very expensive technique and cannot be used on formalin-fixed, paraffin-embedded samples. Recently studies have established thatsimilar subtypes can be identified using immunohistochemical specific markers as surrogate tool for DNA microarray

Manuscript received: $4^{\text {th }}$ March 2019 Reviewed: $10^{\text {th }}$ March 2019

Author Corrected: $15^{\text {th }}$ March 2019

Accepted for Publication: $19^{\text {th }}$ March 2019
[5]. Breast carcinoma subtypes based on immunohistochemical markers are Luminal A, Luminal B, HER2 over expression and Basal cell like. The molecular subtypes suggest the heterogeneity of breast carcinomas and the possible different cell lineage pathways in breast carcinogenesis. The precise prevalence and clinico-pathological characteristics of these molecular subtypes of invasive breast tumours are not extensively studied in Indian population and attempts are being made [6].

\section{Aims and Objectives}

1) To find out the prevalence of various molecular subtypes of breast carcinoma.

2) To correlate molecular sub typing with histological features (histological sub typing and Bloom Richardson grading), clinical stage and other prognostic factors.

3) To correlate MIB1 index with various prognostic factors. 


\section{Material and Methods}

Original Research Article

100 cases of untreated breast cancer patients who underwent surgery in our institute were enrolled for this study after taking required permission from the ethical committee of the hospital. Clinical history, radiological investigations, tumour marker study and other routine investigations of all patients was obtained in detail from case files maintained in our institute.

The surgical specimens were grossed and microscopically examined in our histopathology department. Histopathological diagnosis was made by hematoxylin and eosin staining. The disease was staged according to TNM classification.

Then appropriate tumor block is further processed for immunostaining (done by Ventana Banchmark XT). ER, PR, Her2/neu and MIB1 status were studied for each patient and divided into molecular subtype accordingly.

\section{Inclusion Criteria for study}

1. Cases selected have all four ER, PR, Her2/neu and MIB1 markers done.

2. All cases are diagnosed with invasive malignancy and undergone modified radical mastectomy or lumpectomy/breast c onservation surgery with lymph node dissection in our institute.

\section{Exclusion Criteria for study}

1. Cases with in situ malignancy or benign neoplasm.

2. Cases of lumpectomy/breast conservation surgery without lymph node dissection.

3. Cases which have received treatment in the form of chemotherapy or radiotherapy before undergoing surgery.

ER \& PR status reporting: We have followed Al1 red score for reporting [7,8,9].

\begin{tabular}{|c|c|c|c|}
\hline Proportion Score & Positive cells \% & Intensity & Intensity Score \\
\hline 0 & 0 & None & 0 \\
\hline 1 & $<1$ & Weak & 2 \\
\hline 2 & 1 to 10 & Strong & 3 \\
\hline 3 & 11 to 33 & & \\
\hline 4 & 34 to 66 & & \\
\hline 5 & $>=67$ & & \\
\hline
\end{tabular}

HER2/neu testing by IHC: ASCO and CAP have issued updated recommendations for reporting the results of HER2 testing by IHC [10].

Ki67 (MIB1) Reporting on IHC: In view of significant inter observer variability to evaluate Ki67 index [11] and lack of precise guidelines on measuring M1B1 index [12] we have used following method to count M1B1 index[13].

- In full sections, at least three high-power ( $\times 40$ objective) fields selected to represent the spectrum of staining seen on initial overview of the whole section and minimum 500 malignant invasive cells are counted.

- The invasive edge of the tumor is preferably scored and if there are clear hotspots, data from these included in the overall score.

- Only nuclear staining is considered positive. Staining intensity is not relevant.

- The Ki67 score or MIB1 index expressed as the percentage of positively staining cells among the total number of invasive cells in the area scored. The cut offof $20 \%$ isused to divide low proliferative activity and high proliferative activity $[11,14,15]$.

Statistical analysis: Chi-square test was used to analyse the significance of correlation between various parameters. The value $\mathrm{P}<0.05$ was considered significant. 


\section{Results}

Original Research Article

We have divided all breast carcinomas into molecular subtypes. We noted:

\section{MOLECULAR SUBTYPES}

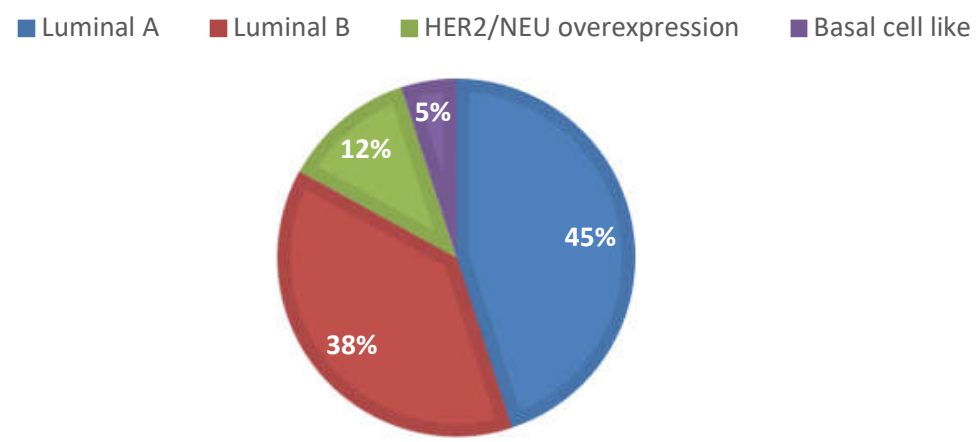

Figure-1: Pie chart depicting frequency of occurrence of various molecular subtype of breast carcinomas.

The most common subtype was luminal A (45\%) followed by Luminal B (38\%), Basal cell like (12\%) and HER2/NEU over expression ( $5 \%$ ) in decreasing proportion.

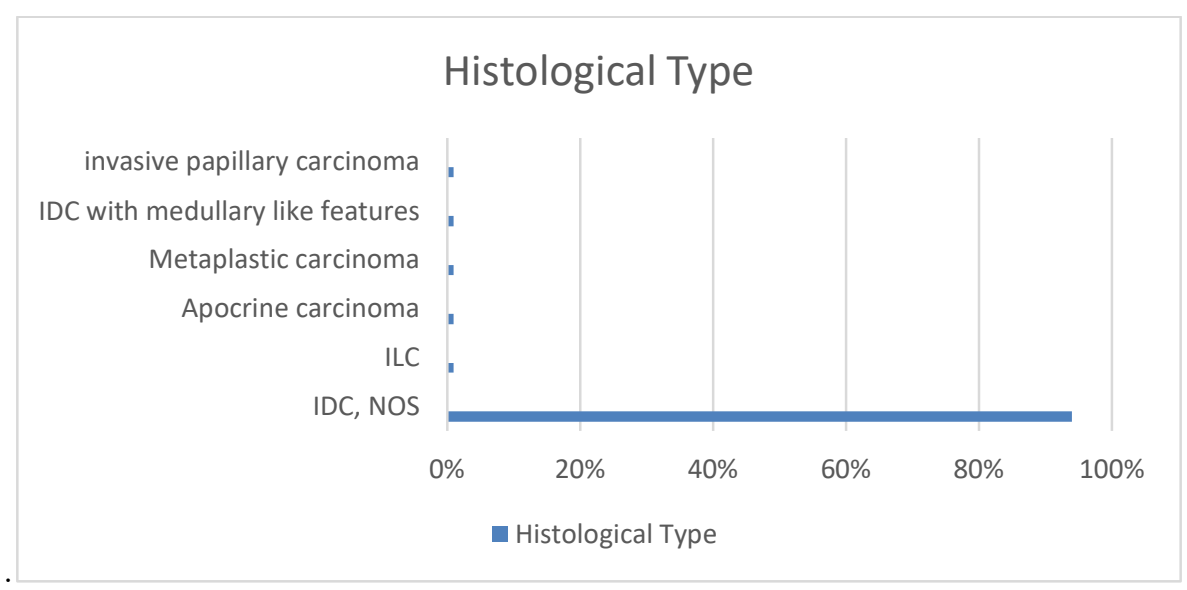

Figure-2: Bar chart depicting percentage occurrence of various histological subtypes of breast carcinomas.

Most common type in our study was Invasive ductal carcinoma. Mostly low grade IDC and Invasive Lobular carcinoma belonged to Luminal A. Most of intermediate and high-grade IDC belonged to Luminal B, HER2/NEU overexpression and BCL types. Metaplastic Carcinoma and IDC with medullary like feature fell into BCL subtype

Table-1: Relationship of BR grade and Molecular subtype (n=100):

\begin{tabular}{|c|c|c|c|c|c|c|}
\hline & \multicolumn{4}{|c|}{ Molecular Subtype } & \\
\hline & & Luminal A & Luminal B & $\begin{array}{c}\text { HER2/NEU } \\
\text { OVEREXPRESSION }\end{array}$ & $\begin{array}{c}\text { BASAL } \\
\text { LIKE }\end{array}$ & \\
\hline \multirow{3}{*}{$\begin{array}{c}\text { BR } \\
\text { grade }\end{array}$} & I & 12 & 4 & 0 & 0 & 16 \\
\hline & II & 33 & 25 & 2 & 5 & 65 \\
\hline & III & 0 & 9 & 3 & 7 & 19 \\
\hline \multicolumn{2}{|c|}{ Total } & 45 & 38 & 5 & 12 & 100 \\
\hline
\end{tabular}

The value of $\mathrm{X}^{2}$ (Chi square) value is 31.78 and $\mathrm{p}$ value is 0.0001 . So, the correlation between BR Grade and molecular subtyping is statistically significant. 
Original Research Article

Table-2: Relationship of molecular subtype and clinical stage $(\mathbf{n}=100)$.

\begin{tabular}{|c|c|c|c|c|c|c|}
\hline & & \multicolumn{4}{|c|}{ Molecular stage } & \multirow[t]{2}{*}{ Total } \\
\hline & & Luminal A & Luminal B & Her2 over expression & Basal like & \\
\hline \multirow[t]{7}{*}{ Clinical stage } & IA & 20 & 13 & 0 & 1 & 34 \\
\hline & IIA & 22 & 21 & 4 & 7 & 54 \\
\hline & IIB & 1 & 2 & 0 & 2 & 5 \\
\hline & IIIA & 1 & 0 & 0 & 2 & 3 \\
\hline & IIIB & 0 & 1 & 1 & 0 & 2 \\
\hline & IV & 1 & 1 & 0 & 0 & 2 \\
\hline & Total & 45 & 38 & 5 & 12 & 100 \\
\hline
\end{tabular}

The X2 (chi square) value is 29.17 and $\mathrm{p}$ value is 0.015 . So, this correlation between clinical stage and molecular subtyping is statistically significant.

Table-3: Relationship of BR grade and M1B1 index $(n=100)$.

\begin{tabular}{|c|c|c|c|c|}
\hline & & \multicolumn{2}{|c|}{ M1BI } & \multirow[t]{2}{*}{ Total } \\
\hline & & $<20 \%$ & $>20 \%$ & \\
\hline \multirow[t]{3}{*}{ BR grade } & I & 14 & 2 & 16 \\
\hline & II & 35 & 30 & 65 \\
\hline & III & 3 & 16 & 19 \\
\hline \multicolumn{2}{|c|}{ Total } & 52 & 48 & 100 \\
\hline
\end{tabular}

The $\mathrm{x} 2$ (chi square) value is 18.14 and $\mathrm{p}$ value is 0.0001 . So, this correlation between BR grade and M1B1 index is statistically significant.

Table-4-: Relationship of Molecular subtype and Axillary Lymph node involvement (n=100):

\begin{tabular}{|c|c|c|c|c|c|c|}
\hline & & \multicolumn{4}{|c|}{ Molecular Subtypes } & \\
\hline & & Luminal A & Luminal B & $\begin{array}{c}\text { HER2/NEU } \\
\text { Overexpression }\end{array}$ & $\begin{array}{c}\text { Basal } \\
\text { like }\end{array}$ & \\
\hline \multirow{2}{*}{$\begin{array}{c}\text { Axillary } \\
\text { LN }\end{array}$} & Uninvolved & 43 & 33 & 5 & 8 & 89 \\
\hline & Involved & 2 & 5 & 0 & 4 & 11 \\
\hline \multicolumn{2}{|c|}{ Total } & 45 & 38 & 5 & 12 & 100 \\
\hline
\end{tabular}

The $\mathrm{X}^{2}$ (Chi square) value is 8.888 and $\mathrm{p}$ value is 0.031 . Hence this correlation between axillary nodal involvement and molecular subtyping is statistically significant.

Table- 5: Relationship of MIB1 index and Lymph node involvement (n=100):

\begin{tabular}{|c|c|c|c|c|}
\hline & & \multicolumn{2}{|c|}{ Axillary LN } & \multirow[t]{2}{*}{ Total } \\
\hline & & Uninvolved & Involved & \\
\hline \multirow{2}{*}{$\begin{array}{l}\text { MIB1 } \\
\text { Index }\end{array}$} & $<20 \%$ & 50 & 2 & 52 \\
\hline & $\geq 20 \%$ & 39 & 9 & 48 \\
\hline \multicolumn{2}{|c|}{ Total } & 89 & 11 & 100 \\
\hline
\end{tabular}

The $\mathrm{X}^{2}$ (Chi square) value is 5.66 and $\mathrm{p}$ value is 0.017 . so, relationship between M1B1 Index and lymph node involvement is statistically significant. 
Table- 6: Relationship of MIB1 index and HER2/NEU positivity (n=100):

\section{Original Research Article}

\begin{tabular}{|c|c|c|c|c|}
\hline & & \multicolumn{2}{|c|}{ HER2/NEU } & \multirow[t]{2}{*}{ Total } \\
\hline & & Negative & Positive & \\
\hline \multirow{2}{*}{$\begin{array}{l}\text { MIB1 } \\
\text { Index }\end{array}$} & $<20 \%$ & 47 & 5 & 52 \\
\hline & $\geq 20 \%$ & 37 & 11 & 48 \\
\hline \multicolumn{2}{|l|}{ Total } & 84 & 16 & 100 \\
\hline
\end{tabular}

The $\mathrm{X}^{2}$ (Chi square) value is 3.38 and $\mathrm{p}$ value is 0.06 . So, this correlation is statistically not significant.

Table-7: Relationship of Molecular subtype and IHC markers (n=100):

\begin{tabular}{|c|c|c|c|c|c|c|}
\hline & & Luminal A & Luminal B & $\begin{array}{c}\text { HER2/NEU } \\
\text { Overexpression }\end{array}$ & $\begin{array}{c}\text { Basal } \\
\text { Like }\end{array}$ & P Value \\
\hline \multirow[t]{2}{*}{ ER } & Negative & 0 & 0 & 5 & 12 & \multirow[t]{2}{*}{0.0001} \\
\hline & Positive & 45 & 38 & 0 & 0 & \\
\hline \multirow[t]{2}{*}{ PR } & Negative & 2 & 8 & 5 & 12 & \multirow[t]{2}{*}{0.0001} \\
\hline & Positive & 43 & 30 & 0 & 0 & \\
\hline \multirow[t]{2}{*}{ HER2/NEU } & Negative & 45 & 28 & 0 & 12 & \multirow[t]{2}{*}{0.001} \\
\hline & Positive & 0 & 10 & 5 & 0 & \\
\hline \multirow[t]{2}{*}{ MIB1 } & $<20 \%$ & 45 & 4 & 1 & 2 & \multirow[t]{2}{*}{0.0001} \\
\hline & $\geq 20 \%$ & 0 & 34 & 4 & 10 & \\
\hline
\end{tabular}

Correlation between molecular subtype and IHC markers are statistically significant.

\section{Discussion}

Though molecular sub typing of breast cancer is not routinely practiced, but it does provide an idea about aggressiveness of tumor, response to treatment and outcome. Similarly, MIB1 index (Proliferative index) also has prognostic significance.

In the present study, 100 patients with invasive carcinoma (all are menopausal women) were included. Among them Luminal A subtype was the most common (45\%) followed by Luminal B (38\%), Basal cell like $(12 \%)$ and HER2/NEU over expression(5\%) in that order. Studies by Sangeeta Verma et al [16] and Nikhilesh Kumar et al. [6] have shown Luminal A to be the most common subtype in Indian women (47\% and $34 \%$ respectively).

Most common histological subtype in present study is Invasive ductal carcinoma Nos type (95\%) which is similar to other Indian studies by Munjal $\mathrm{K}$ et al [17] and Ambroise et al [18] Most low-grade IDC, Nos (75\%) and Invasive lobular carcinoma were of Luminal A subtype. High Grade IDC fell into all three Luminal B, HER2 and BCL subtype. Metaplastic carcinoma and IDC with medullary like features showed Basal cell like property. The association between BR grade and molecular subtyping was found to be statistically significant in our study which is comparable to the study done by Smriti Tiwari et al. [19]. In our study, majority of grade I tumor were belonging to Luminal $\mathrm{A}(75 \%)$ compared to grade II and III which were higher in HER2 overexpression and Basal cell like subtypes. Luminal B also has higher grade groups compared to Luminal A. So histological grading is correlating very well with molecular subtypes.

The statistically significant association was found between lymph node metastasis and molecular subtypes $(p<0.001)$ in a study done by Nahed et al. [20] which is also apparent in our study. In our study, Lymph node positivity was more common in Basal cell like subtype (50\%) compared to Luminal A (4.6\%) and Luminal B $(13 \%)$. As lymph node positivity is related to poor prognosis it is correlating that Basal cell like subtype has poorer prognosis compared to Luminal subtypes.

Though in our study any of HRE2 Over expression class cases didn't show lymph node positivity. Study done by Debarshi Jana et al [21] showed statistically significant correlation between BR scoring and M1B1 index $\mathrm{P}$ value is 0.001 hence correlation is significant 
which is in concordance with our study. So both poor prognostic factors higher BR grade and Higher MIB1 positivity are correlated. The correlation is significant between lymph node involvement and M1B1 index in study done by Sarooma et al [4] with p value 0.017 which is also present in our study which suggest that higher MIB1 grade and lymph node positivity are correlating both of which them are associated with poor prognosis.

Luminal A subtype constitutes $50 \%$ of invasive breast cancer associated with expression of luminal cytokeratin and hormone receptors. $20 \%$ of invasive breast cancer are of luminal B subtype which are associated with expression of luminal cytokeratin and moderate to weak expression of hormone receptors. $15 \%$ of invasive breast cancer are of HER $2 / \mathrm{NEU}$ subtype which show high expression of HER2 gene and low expression of hormone receptors. Remaining 15\% of invasive breast cancers are of basal cell like which are associated with expression of basal epithelial genes, basal cytokeratins and low expression of ER and HER2/NEU[22].

\section{Conclusion}

From this study, it is concluded that Luminal A subtype is the most common molecular subtype among all molecular subtypes $(45 \%)$. and is associated with lower histologic grade, lesser MIB1 index and lower clinical stages as compared to Basal Cell like and HER2/neu overexpression subtypes, which are associated with higher histologic grade, higher MIB1 index, more Her2/neu positivity, more lymph node positivity and higher clinical staging.

Higher MIB1 index was associated with higher histologic grade and more lymph node positivity as compared to lower MIB1 index. So it can be used as independent prognostic factor.

Hence, this study depicts that molecular subtyping of breast cancer aids in estimating progression and prognosis of the disease as basal cell like and HER2/neu overexpression are associated with higher clinical grade than luminal A subtype.

Limitations: As it was study of two years only the patients could not be followed up to find out exact prognostic impact of MIB1 index and molecular subtype. Only correlation was made between known prognostic factors.

Funding: Nil; Conflict of Interest: None initiated Permission from IRB: Yes

\section{Original Research Article}

\section{References}

1.Ferlay J, Soerjomataram I, Dikshit R, Eser S, Mathers $\mathrm{C}$, Rebelo $\mathrm{M}$, et al. Cancer incidence and mortality worldwide: Sources, methods and major patterns in GLOBOCAN 2012. Int J Cancer. 2015; 136: E35986. [PubMed] [Google Scholar]

2. Asthana S, Chauhan S, Labani S. Breast and cervical cancer risk in India: An update. Indian $\mathrm{J}$ Public Health. 2014;58:5-10. [PubMed] [Google Scholar]

3. Murthy N S, Chaudhry K, Nadayil D, Agarwal U K, Saxena S. Changing trends in incidence of breast cancer: Indian scenario. Indian J Cancer 2009;46:73-4

4. Haroon S., Hashmi A.A., Khurshid A. et al. (2013) Ki67 index in breast cancer: correlation with other prognostic markers and potential in Pakistani patients. Asian Pac. J. Cancer Prev. 14, 4353-4358 10.7314/ APJCP. 2013.14.7.4353

5. M. Perou, Charles \& Sørlie, Therese \& B. Eisen, Michael \& van de Rijn, Matt \& S. Jeffrey, Stefanie \& Rees, Christian \& R. Pollack, Jonathan \& Ross, Douglas \& Johnsen, Hilde \& A. Akslen, Lars \& Fluge, Øystein \& Pergamenschikov, Alexander \& Williams, Cheryl \& Zhu, Shirley \& Lønning, Per \& BorresenDale, A.L. \& Brown, Patrick \& Botstein, David. (2000). Molecular portraits of human breast tumours. Nature. 406. 747-52. 10.1038/35021093.

6.Kumar N, Patni P, Agarwal A, Khan MA, Parashar N. Prevalence of molecular subtypes of invasive breast cancer: A retrospective study. Med J Armed Forces India. 2015;71(3): 254-258. doi:10.1016/j.mjafi.2015. 04.006 .

7. Edge SB, Compton CC. The American Joint Committee on Cancer: the 7th edition of the AJCC cancer staging manual and the future of TNM. Ann Surg Oncol. 2010;17:1471-1474.

8.Nadji M, Gomez-Fernandez C, Ganjei-Azar P, Morales AR. Immunohistochemistry of estrogen and progesterone receptors reconsidered. Am J Clin Pathol. 2005; 123 (1):21-27. doi: 10.1309/4WV79N2GHJ 3X 1841].

9. Wolff AC, Hammond MEH, Hicks DG, Dowsett M, McShane LM, Allison KH et al. Recommendations for human epidermal growth factor receptor 2 testing in breast cancer: American society of clinical oncology/ college of American pathologists clinical practice guideline update. Archives of Pathology and Laboratory 
Medicine. 2014 Feb;138(2):241-256. https:// doi. org/ 10.5858/arpa.2013-0953-SA

10. L. Fulawka and A. Halon, "Ki-67 evaluation in breast cancer: The daily diagnostic practice," Indian J. Pathol. Microbiol., vol. 60, no. 2, p. 177, 2017.

11. Fulawka L, Halon A. Proliferation Index Evaluation in Breast Cancer Using Image J and ImmunoRatio Applications. Anticancer Res 2016;36:3965-72. Back to cited text no. 19

12. Dowsett $M$, Nielsen TO, $A^{\prime} H e r n ~ R$, et al. Assessment of Ki67 in breast cancer: recommendations from the International Ki67 in Breast Cancer working group. J Natl Cancer Inst. 2011;103(22):1656-1664. doi: 10.1093/jnci/djr393

13. Bustreo S, Osella-Abate S, Cassoni P, Donadio M, Airoldi M, Pedani F, et al. Optimal Ki67 cut-off for luminal breast cancer prognostic evaluation: a large case series study with a long-term follow-up. Breast Cancer Res Treat. 2016;157:363-71.

14. Tashima R, Nishimura R, Osako T, Nishiyama Y, Okumura Y, Nakano M, et al. Evaluation of an Optimal Cut-Off Point for the Ki-67 Index as a Prognostic Factor in Primary Breast Cancer: A Retrospective Study. PloS one. 2015;10(7): e0119565. PubMed Central PMCID: PMC4503758. pmid:26177501

15. Verma S, Bal A, Joshi K, Arora S, Singh G. Immunohistochemical characterization of molecular subtypes of invasive breast cancer: A study from North India. APMIS 2012;120:1008-19

16. Munjal K, Ambaye A, Evans MF, Mitchell J, Nandedkar S, Cooper K. Immunohistochemical analysis

\section{Original Research Article}

of ER, PR, HER2 and CK 5/6 in Infiltrative breast carcinomas in Indian patients. Asian Pac J Cancer Prev. 2009; 10:773-8.

17. Ambroise M, Ghosh M, Mallikarjuna VS, Kurian A. Immunohistochemical profile of breast cancer patients at a tertiary care hospital in South India. Asian Pac J Cancer Prev 2011;12:625-9.

18. Tiwari Pandey, Smriti \& Malik, Reeni \& Trichal, VK \& K Nigam, R \& Rai, Arvind \& Balani, Sharda \& Jain, Jaya \& Pandey, Dhruvendra. (2015). Breast Cancer: Correlation of Molecular Classification with Clinico-histopathology. Scholars Journal of Applied Medical Sciences (SJAMS). 3. 1018 - 1026.

19. Soliman NA, Yussif SM. Ki-67 as a prognostic marker according to breast cancer molecular subtype. Cancer Biol Med. 2016; 13: 496-504. pmid:28154782

20. Spitale A, Mazzola P, Soldini D, Mazzucchelli L, Bordoni A. Breast cancer classification according to immunohistochemical markers: clinicopathologic features and short-term survival analysis in a population -based study from the South of Switzerland. Annals of oncology: official journal of the European Society for Medical Oncology / ESMO. 2009;20:628-35.

21.Jana D, Sarkar DK, Ganguly S, Banerjee A, Manna AK, Mandal S. Can molecular subtyping replace axillary nodal status as prognostic marker in breast cancer? Indian J Surg Oncol 2014; 5: 282-289.

22. Makki J. Diversity of Breast Carcinoma: Histological Subtypes and Clinical Relevance. Clin Med Insights Pathol. 2015; 8:23-31. Published 2015 Dec 21. doi:10.4137/CPath.S31563

\section{How to cite this article?}

Trivedi P.P, Goel D. K, Patel S., Jetly D.H. ER, PR, M1B1 index and HER2/NEU status in 100 cases of Breast Carcinoma. Trop J Path Micro 2019;5(3):156-162.doi:10.17511/jopm.2019.i03.08. 